\title{
"A VIDA ESCAPA PELOS DEDOS E PELOS MEDOS": O DISCURSO DE LIBERTAÇÃO DOS PAPÉIS SOCIAIS FEMININOS NA SÉRIE TELEVISIVA "OS EXPERIENTES"]
}

\section{"LIFE SLIPS THROUGH FINGERS AND FEARS": THE LIBERATION \\ SPEECH OF FEMALE SOCIAL \\ ROLES IN THE TV SERIES "OS EXPERIENTES"}

Edição v.35 número 2 / 2016

Contracampo e-ISSN 2238-2577

Niterói (RJ), v. 35, n. 2

ago/2016-nov/2016

A Revista Contracampo é uma revista eletrônica do Programa de Pós-Graduação em Comunicação da Universidade Federal Fluminense e tem como objetivo contribuir para a reflexão crítica em torno do campo midiático, atuando como espaço de circulação da pesquisa e do pensamento acadêmico.
MARIA CRISTINA PALMA MUNGIOLI
Professora do Depto. de Comunicaçoes e Artes da ECA-USP e do Programa
Graduação em Ciências da Comunicação da USP. Brasil.
crismungioli@gmail.com
SÍLVIA GÓIS DANTAS
Doutoranda em Ciências da Comunicação pela USP. Bolsista Capes. Brasil.
silviagdantas@gmail.com

\section{PPG $\mid C O M$ Mominecatio UFF}

AO CITAR ESTE ARTIGO, UTILIZE A SEGUINTE REFERÊNCIA:

MUNGIOLI, Maria Cristina Palma ; DANTAS, Silvia Gois. "A vida escapa pelos dedos e pelos medos": o discurso de libertação dos papéis sociais femininos na série televisiva os experientes. Contracampo, Niterói, v. 35, n. 02, pp. 137-157, ago./nov., 2016

Enviado em 10 de novembro de 2015 / Aceito em: 02 de maio de 2016

DOI: http://dx.doi.org/10.20505/contracampo.v35i2.939

1- Versão preliminar desse trabalho foi apresentada no XXXVIII Congresso Brasileiro de Ciências da Comunicação INTERCOM 2015. 


\section{Resumo}

A partir da discussão acerca do envelhecimento da população e da "feminização" da velhice (MOREIRA 1998; SALGADO, 2002) como parte integrante do profundo e complexo processo de transformação da identidade e da intimidade (GIDDENS, 1993, 2002), o presente artigo analisa o discurso da personagem Francisca na série televisiva Os Experientes (Globo, 2015). A análise baseia-se na teoria semiótica narrativa greimasiana a partir dos estudos de Barros (2011) e Fiorin (1996, 2007, 2011). Estudando os processos de figurativização e tematização presentes no texto, foi possível observar a construção de um discurso que aponta para a valorização de novos modelos de velhice feminina, associados à liberdade e à busca da autoidentidade.

\section{Palavras-chave}

Ficção seriada televisiva; gênero e autoidentidade; velhice; série brasileira; Os Experientes.

\section{Abstract}

This article analyses the discourse of social roles for women and their aging in the speeches of Francisca the protagonist in the TV series Os Experientes (Globo TV, 2015). Considering the figurative and thematic analysis, this text takes elements from Greimasian semiotic theory based on the studies realized by Barros (2011) and Fiorin (1996, 2007, and 2011). In addition, the article seeks to point out the discussion on the aging population and the "feminization" of oldness (MOREIRA, 1998; SALGADO, 2002), addressing these issues as part of a deep and complex transformation of identity and intimacy (GIDDENS, 1993, 2002) underway in Brazilian society. The analysis showed positive speeches about new forms of women aging, linked to the women liberation speeches on the search of self-identity.

\section{Keywords}

television serial fiction; gender and selfidentity; oldness; Brazilian series; Os Experientes. 


\section{Introdução}

Caracterizada por sua forte relação com o cotidiano e, portanto, com as alegrias, inquietações e problemas que falam de perto aos brasileiros, a ficção televisiva nacional, sobretudo as telenovelas, mas também as séries e minisséries, nos últimos anos vêm apresentando um protagonismo maior de personagens idosas ${ }^{1}$ em suas tramas. Sob esse enfoque, destacamse personagens do gênero feminino, muitas vezes septuagenárias ou octogenárias, que, fugindo do lugar comum dos papéis sociais (e dramáticos) tradicionais de mulheres nessa faixa etária, vêm assumindo, cada vez mais, um protagonismo que desvela a complexidade das relações humanas, amorosas, profissionais e de gênero que permeiam a sociedade atual.

O presente artigo pretende discutir as transformações de Francisca (Selma Egrei), protagonista do episódio Folhas de Outono da série Os Experientes (Globo, 2015). Analisamos os discursos da protagonista buscando compreender a construção/desconstrução dos papéis sociais da mulher e da velhice feminina nessa ficção, inserindo-a no contexto social contemporâneo. A análise fundamenta-se na teoria semiótica de Greimas e a partir dos trabalhos de Barros (2011) e Fiorin (1996, 2007, 2011). Para subsidiar a discussão, abordamos ainda o envelhecimento da população e a "feminização" da velhice (MOREIRA, 1998; SALGADO, 2002) como parte integrante do profundo e complexo processo de transformação da identidade e da intimidade (GIDDENS, 1993, 2002) em curso na sociedade contemporânea e diante do qual a ficção televisiva brasileira tem se mostrando atenta.

Para compor o quadro de nossas discussões, destacamos que, nos últimos $\operatorname{anos}^{2}$, temos observado a presença mais frequente de personagens femininas acima dos 60 anos com características diversas daquelas que compõem o estereótipo de mãe, tia ou avó donas de casa, muitas vezes mostradas como pessoas assexuadas. Nesse sentido, a título de exemplo e sem a pretensão de realizar um levantamento exaustivo, elencamos algumas produções ficcionais apresentadas nas faixas das 21 e das 23 horas na TV Globo, que, nos últimos anos, caracterizaram-se por um tratamento diferenciado com relação a personagens idosas do gênero feminino, sobretudo no que tange aos relacionamentos amorosos e à sexualidade.

Entre essas produções, destaca-se a minissérie Cinquentinha (Globo,

\footnotetext{
1 Consideramos a definição de idoso explicitada no Estatuto do Idoso (Lei 10.741/2003), que assim denomina a pessoa a partir de 60 anos de idade, limite também adotado pelo IBGE. Disponível em: <http://www.planalto.gov.br/ccivil_03/ leis/2003/L10.741.htm>, acesso em 10/07/2015.

2 Agradecemos a Lucas Martins Néia, auxiliar técnico do Centro de Estudos de Telenovela (CETVN) e bolsista CNPq, a colaboração no levantamento de informações sobre telenovelas e séries abordadas neste artigo.
} 
2009) ${ }^{3}$, que apresentou três mulheres maduras independentes amorosa e profissionalmente que tinham como desafio administrar os bens do exmarido falecido havia pouco tempo. O plot da trama girava em torno dos relacionamentos amorosos e afetivos que as três mulheres administravam sem a interferência da família e sem submissão ao poder masculino. Spin off de Cinquentinha, a série Lara com Z (Globo, 2011) destacava a vida da atriz Lara (Susana Vieira), mostrando também sua independência amorosa e profissional. Já na telenovela Passione (Globo, 2010-2011)5 , ganhou destaque o núcleo de personagens da terceira idade, quase todos octogenários, formado por Antero (Leonardo Villar), Bete Gouveia (Fernanda Montenegro), Diógenes (Elias Gleizer), Benedetto (Emiliano Queiroz) e Brígida (Cleyde Yáconis). Esta última, depois de encontros secretos com o motorista Diógenes, enquanto ainda era casada com Antero, seu segundo marido, envolve-se com Benedetto. Ao final da trama, Brígida, Benedetto e Diógenes terminam juntos em uma espécie de ménage à trois. Em outros núcleos também foram focalizadas personagens mais velhas, como Clô Souza e Silva (Irene Ravache), Olavo da Silva (Francisco Cuoco) e Fortunato (Flávio Migliacio), todas com vida sexual ativa.

Em 2012, o especial de fim de ano Doce de Mãe (Globo, 2012) ${ }^{6}$ trouxe Fernanda Montenegro vivendo a octogenária Picucha, papel que Ihe valeu - Emmy International Awards na categoria Melhor Atriz. A bem-sucedida produção unitária tornou-se série com o mesmo nome, exibida em 2014. ${ }^{7}$

Em 2015, na principal telenovela da Globo, Babilônia ${ }^{8}$, ganhou destaque a homossexualidade feminina na terceira idade com as personagens Estela (Nathália Timberg) e Teresa (Fernanda Montenegro). Fora do contexto brasileiro, mas também se configurando como um exemplo da discussão em torno do papel feminino na terceira idade para além do casamento, a série Grace and Frankie (Netflix, 2015) traz Jane Fonda e Lily Tomlin como protagonistas que têm de se reinventar como mulheres, superando os papéis de esposas e donas de casa, após o fim de um casamento de 40 anos. O ponto de virada em suas vidas ocorre quando os respectivos maridos, também

\footnotetext{
3 Com direção de Wolf Maya e texto de Aguinaldo Silva e Maria Elisa Berredo, a minissérie teve oito episódios e foi levada ao ar de 08 a 18/12/2009, no horário das 23h.

4 Originada de Cinquentinha e também de Aguinaldo Silva e Maria Elisa Berredo, a série Lara com Z teve 14 episódios exibidos de 07/04 a 07/07/2011 e foi dirigida por Wolf Maya.

5 Novela de Silvio de Abreu, com colaboração de Sérgio Marques, Vinicius Vianna, Daniel Ortiz. Teve 209 capítulos e foi exibida de 17/05/2010 a 14/01/2011, no horário das 21h. Direção de Natalia Grimberg, Allan Fiterman e André Câmara.

6 Roteiro de Ana Luiza Azevedo, Jorge Furtado e Miguel da Costa Franco. Direção de Ana Luiza Azevedo e Jorge Furtado. O especial de fim de ano foi ao ar em 27/12/2012.

7 Também nesse ano, em 12/12/2014, a Record exibiu o telefilme Manual Prático da Melhor Idade, com texto de Renê Belmonte e direção de Adolfo Rosenthal, no qual um asilo de idosos foi o cenário para o encontro de quatro mulheres.

8 De Gilberto Braga, Ricardo Linhares e João Ximenes Braga, Babilônia estreou em 16/03/2015, com direção de Denis Carvalho.
} 
sócios e amigos, declaram-se gays e apaixonados um pelo outro, destruindo a estabilidade de seus lares, que até então Ihes parecia inabalável.

De volta ao cenário das produções nacionais que tiveram o cotidiano da velhice como ponto de partida, apresentamos o objeto da presente análise: a série Os Experientes. Podendo ser classificada como uma série de antologia, ou seja, com trama e personagens distintos a cada episódio, a coprodução da Globo e 02 Filmes foi exibida na Globo no horário das 23 horas em quatro episódios - de 10/04 a 01/05/2015, às sextas-feiras - com roteiro assinado por Márcio Alemão e Antônio Prata e direção de Gisele Barroco, Fernando Meirelles e Quico Meirelles.

O primeiro episódio, O Assalto, mostrou Yolanda (Beatriz Segall) como refém de um assalto a banco durante o qual assume papel central na condução da libertação de reféns. Na segunda semana, Atravessadores do Samba trazia o grupo de músicos septuagenários formado por Oswaldo (Goulart de Andrade), Mateus (Wilson das Neves) e Amaro (Zé Maria), tentando retomar a carreira após a morte de um dos membros - Lucas Pereira (Germano Mathias). A terceira trama da série, O Primeiro Dia, contou a história de Napoleão Roberto (Juca de Oliveira), que recebe o diagnóstico de uma doença incurável que Ihe dá pouco tempo de vida. Confrontado com a finitude da vida, Napoleão tenta se reaproximar do filho Luiz (Dan Stulbach). Por fim, o quarto episódio, Folhas de Outono, objeto de discussão neste artigo, narra a história de Francisca, que, após o falecimento do marido, toma para si as rédeas de sua vida. Um maior detalhamento deste episódio será feito adiante.

\title{
Transformações nas formas de amar: do amor romântico ao amor confluente
}

Segundo declarou Quico Meirelles, a ideia da série surgiu a partir do desejo de mostrar as possibilidades de uma fase da vida:

\begin{abstract}
Estávamos em uma onda de desenvolver ideias para séries. Pensando no assunto, me ocorreu que quase não temos programas sobre a terceira idade e com atores mais velhos. [...] A principal mensagem é de que envelhecer tem um lado positivo, que nunca é tarde para as coisas, sempre é possível se reinventar. Nunca é tarde para mudar o jeito que você é ou se emocionar de um jeito diferente. (SANTOS, 2015, online)
\end{abstract}

Nas palavras do diretor, podemos entrever pontos que nos levam a considerar as discussões em torno das identidades de gênero que não se restringem à terceira idade, mas que também para ela confluem como características da construção social do ser humano na atualidade. Giddens 
(1993, 2002) discute como ponto de inflexão das transformações da intimidade e da identidade o protagonismo feminino ocorrido depois da Segunda Guerra Mundial e mais marcadamente após o advento da pílula anticoncepcional.

Cabe, no entanto, lembrar que, para Giddens (1993, 2002), as transformações referentes à sexualidade e à autoidentidade devem ser estudadas dentro da complexidade dos contextos históricos da Modernidade, caracterizados pelo fortalecimento da confiança nos sistemas abstratos que, entre outras coisas, garantem ao indivíduo a possibilidade e a liberdade de se autoidentificar por meio do desenvolvimento da reflexividade. O autor destaca que, nesse contexto, a identidade sexual ou a autoidentidade, em sentido mais amplo, representam "um projeto conduzido em meio a uma profusão de recursos reflexivos: terapia, manuais de autoajuda de todos os tipos, programas de televisão e artigos de revistas" que permitem a elaboração de "uma narrativa coerente do eu em relação ao futuro" (GIDDENS, 2002, p. 71).

Entre os aspectos destacados pelo sociólogo como característicos da construção da autoidentidade, ganha relevo a transformação do amor romântico, tão característico da literatura e dos produtos da indústria cultural veiculados na televisão e no cinema. Um dos grandes pilares do melodrama, e, portanto, das telenovelas e da ficção televisiva em geral, o amor romântico ancora-se na procura da alma gêmea e na perenidade do sentimento amoroso, sendo seu objetivo final o encontro do masculino que possa validar a autoidentidade feminina.

Tal configuração simbólica sofre, de acordo com Giddens (1993, 2002), grande transformação devido a lutas de movimentos feministas identificados com os ideais de emancipação, que levaram as mulheres à busca e à construção de relacionamentos ancorados na igualdade de gêneros, a partir do questionamento dos discursos de subordinação ao gênero masculino e da luta contra a hegemonia masculina amparada em amplo sistema legal. Todo esse movimento deve ainda ser visto no contexto das profundas mudanças que afetaram a sexualidade no último quarto do século $X X$, como salienta Giddens (1993, p. 23). Dentro desse cenário, este autor destaca o surgimento da "sexualidade plástica", ou seja, a sexualidade dissociada da reprodução e dos ideais do casamento tradicional e que passa a se constituir como eixo dos relacionamentos amorosos, sejam eles heterossexuais ou homossexuais. Essa nova configuração leva ao que o autor chama de "relacionamento puro", que se configura como a chave do amor confluente, isto é, uma relação que "só continua enquanto ambas as partes considerarem que extraem dela satisfações suficientes, para cada uma individualmente, para nela permanecerem". (GIDDENS, 1993, p. 69). 
Mais estritamente, falando sobre as formas de entretenimento contemporâneas, Giddens destaca o papel estruturante que as narrativas das telenovelas ocupam como modelos de "construção de narrativas do eu" (GIDDENS, 2002, p. 184) fundamentais para os processos de autoidentidade. Para o autor, as narrativas de telenovelas proporcionariam elementos para a constituição de uma narrativa coerente (e estruturante) do eu, já que

\begin{abstract}
as telenovelas misturam previsibilidade e contingência ligeiramente perturbadoras, mas ao mesmo tempo tranquilizadoras. Elas oferecem misturas de contingência, reflexividade e sina. A forma conta mais que o conteúdo; nessas estórias ganha-se uma sensação de controle reflexivo sobre as circunstâncias da vida, uma sensação de uma narrativa coerente que é um equilíbrio tranquilizador para as dificuldades de sustentar a narrativa do eu em situações sociais reais (GIDDENS, 2002, p. 184).
\end{abstract}

No caso da sociedade brasileira, e, especificamente falando, em termos de relações amorosas, Priore (2005) afirma a importância da televisão a partir da década de 1960 no debate sobre o assunto, mostrando novas configurações de relacionamentos.

\title{
A feminização da velhice
}

Em paralelo com as transformações na intimidade e nas relações de gênero, cabe enfatizar que desde 1970, quando foi publicada a obra $A$ velhice, de Simone de Beauvoir, denunciando a conspiração do silêncio que sufocava essa fase da vida, o contexto se modificou. Segundo Debert (2012), foi a partir dessa década, sobretudo, que os estudos sobre envelhecimento começaram a se desenvolver. Hoje, falar sobre o envelhecimento da população diante da diminuição das taxas de natalidade e do aumento da longevidade, já se tornou comum. Trata-se de um fenômeno mundial - e também brasileiro diagnosticado por diversos censos e projeções.

Os dados projetados pela Organização das Nações Unidas revelam que a proporção de pessoas com 60 anos ou mais em todo o mundo irá duplicar nas próximas décadas, devendo alcançar a marca de dois bilhões até 2050. Dentre os idosos, a faixa populacional que mais cresce é aquela que compreende os indivíduos acima de 80 anos. (CASTRO, 2015, p. 2)

Considerado até recentemente um país jovem, o Brasil de hoje apresenta mudanças significativas na composição etária da sua população. A pirâmide demográfica, antes concentrada principalmente em uma expressiva base - marcada pelas crianças -, começa a se alterar de forma paulatina e constante. Segundo os mais recentes indicadores do IBGE, a tendência de 
envelhecimento da população vem se mantendo (IBGE, 2014). Embora na pirâmide demográfica brasileira ainda predominem as faixas de 10-19 e de 30-39 anos, o envelhecimento gradual da população torna central para os estudiosos de Comunicação e, em particular, da ficção televisiva, a questão social do envelhecimento e da construção da imagem do idoso pela mídia. Esses números e a consequência social por eles produzida fazem a questão do envelhecimento emergir fortemente.

A preocupação recente com o envelhecimento e com a melhoria da qualidade de vida dos mais velhos na sociedade brasileira muda não apenas a sensibilidade investida na velhice, mas é também traduzida em um conjunto de práticas concretas inesperadas no script dos papéis femininos e masculinos na velhice que consideramos próprios da nossa sociedade. (DEBERT, 2012, p. 143)

Na tabela abaixo, é possível observar o crescimento gradual da expectativa de vida dos brasileiros.

Tabela 1. Expectativa de vida do brasileiro ao nascer (2000-2060)9

\begin{tabular}{|c|c|}
\hline ANO & EXPECTATIVA \\
\hline 2000 & 69,8 anos \\
\hline 2010 & 73,9 anos \\
\hline 2020 & 76,7 anos \\
\hline 2030 & 78,6 anos \\
\hline 2040 & 79,9 anos \\
\hline 2050 & 80,7 anos \\
\hline 2060 & 81,2 anos \\
\hline
\end{tabular}

A população de idosos no Brasil é composta majoritariamente por mulheres: $55,5 \%$ contra $44,5 \%$ de homens (IBGE, 2014). Os números evidenciam o fenômeno da "feminização da velhice" destacado por Moreira (1998, p. 88), ao explicar que "é muito maior o número de mulheres que sobrevivem até atingir o limiar inferior do grupo etário idoso e, uma vez fazendo parte dele, nele permanecem por muito mais tempo do que os homens". Salgado (2002, p. 9) também reforça que "o fato mais significativo e simples sobre a velhice é que a população idosa é predominantemente

9 Fonte: a partir de dados do IBGE: CARPES, Giuliander. Pnad: população idosa no Brasil cresce, vive mais e começa a usar a internet. Uol notícias. 27 set. 2013. Disponível em: <http://noticias.uol.com.br/cotidiano/ultimas-noticias/2013/09/27/ pnad-populacao-idosa-no-brasil-cresce-vive-mais-e-comeca-a-usar-a-internet.htm>. Acesso em: 23 set. 2015. 
feminina".

Diante desse quadro e frente às alterações na compreensão da construção identitária e da constituição do amor confluente como uma das principais características da atualidade, ganha relevo a noção de gênero. Tal categoria implica a compreensão das relações de poder entre os sexos e deve ser entendida enquanto construção social, ou seja, uma "criação inteiramente social de ideias sobre os papéis adequados aos homens e às mulheres. Trata-se de uma forma de se referir às origens exclusivamente sociais das identidades subjetivas de homens e de mulheres" (SCOTT, 1995, p.75). No mesmo sentido, Hérnandez García (2006) destaca que:

A dimensão política do gênero desvela as relações desiguais dos gêneros que atravessam todas as esferas da vida social, moldando, determinando e construindo possibilidades assimétricas e hierárquicas quanto ao acesso aos recursos materiais e simbólicos, ao desenvolvimento econômico, à cultura e à própria vida, relação na qual as mulheres são as menos favorecidas. (p. 9)

Nesse cenário, Debert (2012) salienta, com base em depoimentos, as distintas formas com que homens e mulheres se relacionam com a velhice e registra como os novos papéis sociais surgidos a partir da aposentadoria e/ou da chegada aos 60 anos também se redefinem. As mulheres veem na velhice a possibilidade de maior liberdade, identificada com o momento em que poderão criar as próprias regras e ter mais independência, em contraste principalmente com a obrigação de realização de tarefas domésticas tão associadas ao feminino no Brasil. Já os homens situam-se em posição diametralmente oposta: "nenhum dos entrevistados considerou que poderia estar vivendo uma experiência privilegiada em relação às outras etapas da vida, mesmo quando avaliava que seu poder aquisitivo era maior do que antes" (DEBERT, 2012, p.186).

Longe de buscar generalizações, a pesquisa indica pistas de modos diferentes de encarar a velhice a partir da mudança de papéis. Os homens entrevistados pela autora fazem referências melancólicas à velhice do passado, quando os pais e avôs eram respeitados. Já as mulheres, apesar da condição de dupla vulnerabilidade, como mulher e idosa, identificada por alguns autores (SALGADO, 2002, p. 13; DEBERT, 2012, p. 140), tendem a perceber na velhice saudável um novo momento de descobertas e emancipação, principalmente para aquelas que foram criadas sem perspectivas de estudos e carreira e dedicaram-se ao casamento, filhos e tarefas do lar, ficando restritas a uma vida com papéis claramente definidos: "no mundo contemporâneo, a conquista da liberdade feminina é, para elas, um fato irreversível e redefine o que é envelhecer. Pela primeira vez é aberto um espaço para as mulheres de 
mais idade criarem novas regras e estilos de vida" (DEBERT, 2012, p. 185).

Em comum entre o masculino e o feminino, está a negação da velhice - velho é sempre o outro. Seja qual for a idade, os idosos não se definem como velhos. Exemplar nesse sentido é a situação de muitos deles não aceitarem ficar na fila de idosos ou sentar nos assentos a eles destinados nos transportes públicos, como se rejeitassem o papel de velho. Também Barros (2006) mostra como estereótipos contaminam o conceito da velhice, fazendo com que ela seja negada.

A velhice, como estigma, não está necessariamente ligada à idade cronológica. Os traços estigmatizadores da velhice evidenciados na literatura analisada ligam-se a valores e conceitos depreciativos: a feiura, a doença, a desesperança, a solidão, o fim da vida, a morte, a tristeza, a inatividade, a pobreza, a falta de consciência de si e do mundo. (BARROS, 2006, p. 139)

Por essa razão, "velho" não se torna uma categoria de autoidentificação, "o velho é sempre um outro e a velhice, um drama de todos em qualquer idade, porque todos ficarão velhos um dia." (DEBERT, 2012, p. 229).

\section{0 discurso da terceira idade}

Para investigar a construção discursiva da velhice feminina, consideramos o cenário social de novos indicadores etários. A isto se soma o entendimento de gênero como construção social e também a ideia da velhice como algo não desejado, compactado na expressão "velho é o outro".

Associado sobretudo às formações discursivas que se estruturam sobre estereótipos negativos, o idoso configura-se como um interlocutor de grande complexidade. Como falar sobre ele e com ele? Como se comunicar com alguém que não se identifica com os discursos verbo-visuais a ele associados? Nesse contexto, surgem novos enunciados que buscam definir essa fase da vida, ou, pelo menos, como ela se apresenta na atualidade, algo que só acontece de fato quando se amplia o poder - econômico, social e cultural dessas pessoas. Como explica Debert (2010), a terceira idade é uma criação recente, surgida para denominar um período entre a idade adulta e a velhice, a partir do crescimento desse público também como mercado consumidor de bens e produtos. Surgem, assim, enunciados que marcam a construção de sentidos positivos em contraposição aos reiteradamente negativos que caracterizam historicamente os idosos na sociedade ocidental:

[...] a terceira idade substitui a velhice; a aposentadoria ativa se opõe à aposentadoria; o asilo passa a ser chamado de centro residencial, o assistente social, de animador 
social e a ajuda social ganha o nome de gerontologia. Os signos do envelhecimento são invertidos e assumem novas designações: "nova juventude", "idade do lazer". Da mesma forma, invertem-se os signos da aposentadoria, que deixa de ser um momento de descanso e recolhimento para tornar-se um período de atividade e lazer. (DEBERT, 2012, p. 61)

Além da "nova juventude" e da "idade do lazer", podemos citar ainda a expressão "melhor idade", utilizada prioritariamente com fins mercadológicos e bastante recorrente em comerciais de televisão que oferecem, por exemplo, pacotes turísticos, conforme o entendimento de que viajar seria um ótimo divertimento para esse público, de acordo com as novas exigências de "atividade e lazer" trazidas por essa fase. Como complementa Debert (2012, p. 213), "mais do que definir a última etapa da vida, trata-se de impor estilos de vida, criando uma série de regras de comportamento e de consumo de bens específicos, que indicam como aqueles que não se sentem velhos devem proceder".

Tendo a promessa da eterna juventude como subtexto, as novas imagens do envelhecimento parecem buscar adaptar-se a "um contexto marcado por mudanças culturais que redefinem a intimidade e a construção das identidades" (DEBERT, 2012, p. 226). Assim, a velhice é identificada pela liberdade, sem obrigações de trabalho e cuidado/manutenção de filhos e parentes, em que os idosos poderiam aproveitar a vida dedicando-se ao que gostariam.

A transformação da velhice em segmento de consumo, a construção discursiva do ideário ageless e da juventude como valor articulam as formas de discriminação com base no preconceito etário. Ao contrário de outras formas de discriminação já mais amplamente combatidas, o idadismo (ageism) é um preconceito amplamente disseminado embora ainda pouco discutido nas ciências sociais, notadamente no campo da Comunicação. (CASTRO, 2015, p.4)

Também nas produções ficcionais, como nas telenovelas, Debert (2012) identifica esse culto à juventude e à atividade como forma de se manter em movimento a fim de fugir da própria passagem do tempo e das suas consequências. Porém, ao mesmo tempo ela destaca mudanças que vêm ocorrendo nesse segmento de ficção.

A expressão do abandono e da solidão nas novelas têm certamente nos velhos um elemento forte, mas eles agora são também apresentados como ativos, capazes de oferecer respostas criativas ao conjunto de mudanças sociais, reciclando identidades anteriores, desenvolvendo novas formas de sociabilidade e de lazer e redefinindo as relações com a família e os parentes. (DEBERT, 2012, p. 218) 


\section{Tematização e figurativização}

Buscando analisar como a série televisiva Os Experientes constrói discursivamente o tema da velhice, recorremos à teoria semiótica do texto proposta por Greimas. Em primeiro lugar, é preciso lembrar que tal perspectiva "tem por objeto o texto, ou melhor, procura descrever e explicar $o$ que $o$ texto diz e como ele faz para dizer o que diz" (BARROS, 2011, p. 7, grifos no original).

Trata-se, portanto, de considerar a dupla face do texto, ou seja, como objeto de significação e também de comunicação. Essa dualidade exige que se analise tanto os mecanismos internos do texto quanto os aspectos sóciohistóricos de construção de sentido, a qual ocorre por meio de formações ideológicas específicas da sociedade em dado momento histórico. Com essas premissas, a semiótica analisa os sentidos do texto a partir de um percurso gerativo, proposta teórico-metodológica que compreende três etapas sucessivas: o nível fundamental, o nível narrativo e o nível discursivo do texto.

A primeira etapa do percurso, a mais simples e abstrata, recebe o nome de nível fundamental ou das estruturas fundamentais e nele surge a significação como uma oposição semântica mínima; no segundo patamar, denominado nível narrativo ou das estruturas narrativas, organiza-se a narrativa, do ponto de vista de um sujeito; o terceiro nível é o do discurso ou das estruturas discursivas em que a narrativa é assumida pelo sujeito da enunciação. (BARROS, 2011, p. 8)

Em razão dos objetivos deste artigo, realizamos uma breve explanação do nível discursivo tendo como base os estudos de Barros (2011) e Fiorin $(1996,2007,2011)$. A estrutura discursiva é caracterizada pela presença do sujeito da enunciação e sua atuação ocorre por meio de escolhas: de pessoa, tempo, espaço, figuras, temas etc. Conforme afirma Fiorin (2011, p. 55), "a enunciação é o ato de produção do discurso, é uma instância pressuposta pelo enunciado (produto da enunciação). Ao realizar-se, ela deixa marcas no discurso que constrói". É por meio das marcas deixadas no discurso que é possível chegar ao sujeito e às condições de produção do texto dentro do contexto sócio-histórico.

No nível discursivo, a semiótica do texto analisa duas categorias: a semântica discursiva e a sintaxe discursiva. A primeira investiga os procedimentos que conferem significação ao discurso (a tematização e a figuratização), e a segunda enfatiza as relações, tanto do sujeito da enunciação com o discurso-enunciado como também entre o enunciador e o enunciatário. 
É ainda na sintaxe discursiva que são analisadas as projeções da enunciação, buscando observar os efeitos de sentido produzidos pelo ato de enunciação, como o efeito de proximidade ou distanciamento da enunciação.

Já a categoria da semântica discursiva estuda a associação dos dois níveis de concretização do sentido: a tematização e a figurativização, recursos ligados à oposição abstração/concretude (FIORIN, 2011, p. 90). No entanto, como adverte o autor, tais níveis compõem um continuum, ou seja, indo do maior nível de abstração (tema) para a concretude (figura). Não se trata, portanto, de níveis estanques ou completamente opostos, uma vez que a significação é construída por meio de ambos. Resumindo, Fiorin, afirma:

Para uma análise de texto não interessam a figura ou o tema isolados. Para achar o tema que dá sentido às figuras ou o tema geral que unifica os temas disseminados num discurso temático, é preciso apreender os encadeamentos das figuras ou dos temas, ou seja, os precursores figurativos ou temáticos. [...] o nível dos temas e das figuras é o lugar privilegiado da manifestação da ideologia. (FIORIN, 2006, p. 106)

Dessa forma, a semântica discursiva possibilita analisar os importantes efeitos de sentido que se constroem no discurso e desvelam o enunciador, e, de forma mais abrangente, o contexto social de onde a obra emana.

A partir dessa breve delimitação do nível discursivo do texto como foco da nossa análise, sobretudo nos recursos de figurativização e tematização, observamos como se produzem sentidos, no episódio em questão, da mulher idosa e de sua sexualidade nos dias de hoje.

\section{Folhas de Outono: tematização e figurativização}

Em razão da abordagem em torno do papel social da mulher de terceira idade após o fim do casamento e frente ao envelhecimento, Folhas de Outono, último dos quatro episódios exibidos na série ${ }^{10}$, é o foco de nossa análise, uma vez que esse problema se configura como um dos eixos da pesquisa de doutorado de uma das autoras deste artigo. Para a realização da discussão proposta, transcrevemos a seguir alguns enunciados do episódio, buscando

10 O quarto episódio, Folhas de Outono, apesar do desenvolvimento independente em termos de trama, apresenta relação com os episódios anteriores não apenas por meio da abordagem temática, mas também pela presença de personagens desses episódios. Embora a aparição desses personagens seja apenas como figurantes, cabe destacar o interdiscurso criado por esse artifício narrativo. Como exemplos dessa construção interdiscursiva, citamos as seguintes cenas: enquanto Francisca sai do cemitério, vemos Roberto (Juca de Oliveira) e seu filho Luiz (Dan Stulbach), do episódio O Primeiro Dia, caminhando entre os jazigos. Também desse episódio, aparece o advogado Del Bello (Othon Bastos) na reunião entre amigos que Francisca realiza em sua casa para apresentar-Ihes a namorada. Já na cena do baile, estão no palco os Atravessadores do Samba, título do episódio e do grupo. Há ainda a referência ao assalto ao banco, o tema do primeiro episódio, quando Francisca pergunta ao filho Daniel (Eucir de Souza): "Bateram na sua cabeça no assalto lá do banco?". 
contextualizá-los em relação ao arco narrativo central que gira em torno de sua protagonista: Francisca (Selma Egrei).

O título do último episódio remete diretamente ao sucesso Autumn Leaves, de Nat King Cole, que aparece interpretando a música na abertura do episódio e integra a diegese, uma vez que as personagens se referem à canção durante a história.

Trata-se da história de Francisca, mulher em torno dos 65 anos, com um casal de filhos adultos, Neide (Silvia Lourenço) e Daniel (Eucir de Souza). Após a morte do marido, ela subitamente se percebe livre. Enquanto os filhos choram, ela sai do cemitério com a amiga Mary (Anamaria Barreto) e, no carro, decide não ir para casa.

FRANCISCA: - Aliás, não vamos para casa não, quero comprar camisolas. Muitas. Transparentes. Leves. Sexy.

MARY: - Num sexy shop ou num shopping mesmo serve? [elas riem]

FRANCISCA: - Uma coisa tão besta. O Arlindo não me deixava dormir de camisola. Dizia que era coisa de mulher vulgar.

MARY: - E você dormia como? De pijama?

FRANCISCA: - Pijamão.

A cena se passa dentro do carro de Mary. Os vidros abertos e o vento balançando os cabelos das duas mulheres remetem à liberdade e às imagens de filmes do gênero road movie que se prefiguram como viagens de autoconhecimento e, em certos casos, de libertação. "Camisolas", "leves", "transparentes" e "não-casa" começam a construir um percurso figurativo da liberdade em contraposição ao aprisionamento do casamento, representados pelo "pijamão". Salienta-se ainda a oposição entre camisola (vulgar) x pijamão (não vulgar) em que a camisola, vestimenta feminina, surge em oposição a pijama, peça de vestuário que pode ser usada por homens e mulheres. Tematiza-se a não-feminilidade (imposição do marido) versus a feminilidade (característica e desejo de Francisca).

Na sequência da trama, os dias vão passando em meio a lembranças e tentativas de seguir em frente, mas também de tropeços, como acontece quando Francisca prepara a mesa para o marido - o jornal, os comprimidos, a torrada e o café ficam à espera de quem (não) virá. Ela se dá conta do lapso e chora. Ativando o espectador por traços de revestimento sensorial, "jornal", "comprimidos", "mesa", "café" e "torrada" figurativizam a dedicação da viúva, por meio do cuidado dedicado ao marido (morto), representado pela cadeira vazia. A tematização da solidão ganha os contornos dos objetos diários que marcaram a intimidade e a rotina do café matinal. Na cena seguinte, Francisca conversa com a amiga Mary sobre os 45 anos de casamento. 
FRANCISCA: - Uma vida, hein?

MARY: - Será?

FRANCISCA: - Tá brincando né? O que sobrou?

MARY: - Para com isso, você tá bonitona, cheia de saúde, cheia de camisola sexy. [...] Quantos foram bons?

FRANCISCA: - Ah... bom... nos últimos cinco eu fui enfermeira dele, né? Nos primeiros quinze anos eu fui babá e motorista das crianças.

MARY: - O Arlindo tirava o pijama pra transar?

FRANCISCA: - [ri]. Imagina...

MARY: - Não?

FRANCISCA: - Nem o meu nem o dele.

MARY: - Sem graça.

FRANCISCA: - Esses 25 anos que sobraram, né? Onde é que eu estava nesses 25 anos? Eu não sei...

Esse trecho é bastante indicativo do papel social conferido à mulher no casamento para a geração que medeia os 65 anos na atualidade: cuidar do marido, tornando-se "enfermeira" com a sua doença; ser "babá" e "motorista" dos filhos nos primeiros quinze anos do casamento. Analisando a história do amor no Brasil, Priore (2006) ressalta a situação de conformismo e servidão das mulheres aos maridos e filhos e seu confinamento ao ambiente doméstico, principalmente até os anos 1960-70, pois o único local de satisfação pessoal era o lar. A moral tradicional - defendida pela sociedade, pela família e pela Igreja - estava intrinsecamente associada à repressão sexual das mulheres, cujo comportamento deveria ser sempre recatado e passivo. A palavra sexo não devia sequer ser pronunciada, tamanho o empenho em valorizar a castidade e a pureza. Nesse sentido, em outra obra, a autora destaca como o sexo era tratado.

No casamento, a afinidade sexual era um fator menos importante no ideal de felicidade, mesmo porque a mulher não tinha nem deveria ter conhecimentos sobre a matéria. Casais iam para cama de camisola e pijama, e luz apagada. Revistas femininas ainda usavam eufemismos para tratar da questão: "ajustamento sexual para união feliz". (PRIORE, 2013, p. 56)

Conforme enfatiza Priore (2013) em relação à geração de mulheres da qual Francisca faria parte, o sexo foi marcado por tabus, não se tirava a roupa, não havia espaço nem mesmo para certos tipos de camisolas consideradas vulgares. Recato, dedicação e doação são os temas que surgem na cena analisada. Ao mesmo tempo, surge a constatação da negação de si mesma como mulher, como indivíduo. O cerne dessa questão está no enunciado no qual ela se pergunta onde estava nos 25 anos em que não fora enfermeira ou cuidara dos filhos. 
Essa fala surge como um ponto de virada na vida de Francisca, a personagem começa a perceber que precisa refazer a vida e descobrir a si mesma. O falecimento do marido pode ser considerado um "momento decisivo" (GIDDENS, 2002) que reforça a crescente reflexividade do indivíduo na Modernidade.

Como os momentos decisivos, por definição, são de alta consequência, o indivíduo se sente numa encruzilhada em termos de seu planejamento geral da vida. Momentos decisivos são fases em que as pessoas podem procurar refúgio em crenças preestabelecidas e em modelos familiares de atividade. Por outro lado, momentos decisivos muitas vezes também marcam períodos de requalificação e empoderamento. (GIDDENS, 2002, p. 134)

Francisca sente o controle do filho, que reclama com a irmã que a mãe passa o "dia fora e chega com bafo de álcool", reclamando que "o momento é de luto e não de farra". A filha tenta contemporizar afirmando que a mãe precisa distrair-se: "A mamãe tá de luto sim. Mas ela não precisa ficar em casa chorando". A resposta do filho é direta: "Pois deveria. Deveria." Constróise por meio do discurso do filho a expectativa do papel social feminino, segundo o qual a mulher "deveria" estar em casa, chorando a dor da perda do falecido esposo. O estranhamento do filho em relação à constatação da irmã de que a mãe está bem evidencia a violência simbólica conforme discute Bourdieu (2010), calcada na dicotomia entre a superioridade masculina e a inferioridade feminina, cuja identidade é ancorada na dependência da mulher em relação ao homem.

As divisões constitutivas da ordem social e, mais precisamente, as relações sociais de dominação e de exploração que estão instituídas entre os gêneros se inscrevem, assim, progressivamente, em duas classes de habitus diferentes [...] que levam a classificar todas as coisas do mundo e todas as práticas segundo distinções redutíveis à oposição entre o masculino e o feminino. (BOURDIEU, 2010, p. 41)

Vivendo o luto à sua maneira, Francisca oscila entre o gozo da liberdade recém-conquistada e a opressão das obrigações familiares e domésticas, das quais tenta se desvencilhar, como se pode perceber em uma conversa da personagem com a filha ao telefone.

FRANCISCA: Eu sei que sábado era o nosso dia, do nosso almoço de família, mas não vai dar. Eu não tô com nenhuma vontade de ir pra cozinha. E aí prepara o almoço, e aí serve a mesa. E a gente acaba falando do Arlindo, eu sei que eu vou acabar chorando... Eu não que... [interrompida]. Tá, tá, tá bom, então vamo fazer uma coisa... Tá, chega. Tá bom. Eu vou fazer. Pelo chato do seu irmão, eu vou fazer o almoço. Tá bom, minha filha? 
A figurativização, aqui, compõe o clima familiar marcado pela coletividade: "nosso dia", "nosso almoço de família", "a gente acaba falando do Arlindo". No entanto, percebe-se que, embora as atividades prazerosas sejam vividas em conjunto pelo grupo familiar, as obrigações cabem somente a ela: "E aí prepara o almoço"; "e aí serve a mesa". Nessa construção discursiva, observamos uma disjunção entre os sujeitos da enunciação que marcam a ação construída na terceira pessoa por meio da debreagem enunciva, ou seja, quando há a exclusão do "eu" do ato da enunciação de Francisca. Tal disjunção gera um efeito de sentido de objetividade, de distanciamento, que pode tanto indicar a tentativa de fugir das tarefas, com as quais ela não se identifica e não deseja, quanto sugerir que não deseja entrar em contato com a tristeza e a dor provenientes das lembranças desses momentos em família. Essa última hipótese parece se confirmar pela conclusão dela ao enunciar: "eu sei que eu vou acabar chorando...". Em virtude desse peso, Francisca justifica-se e insiste com a filha afirmando que "não vai dar"; "Eu não tô com nenhuma vontade de ir pra cozinha".

O prazer de ter os filhos à mesa não é recompensa suficiente para as tarefas domésticas - às quais sempre se submeteu - naquele momento e para o clima de luto que então se instauraria. No entanto, devido à insistência da filha, que pede em nome do irmão, Francisca acaba aceitando preparar o almoço, ainda que a contragosto. Ou seja, após libertar-se da presença física do marido, agora ela se vê diante de um novo homem que se julga no direito de controlar seu destino. Nem mesmo depois de viúva ela é dona do seu tempo e de suas ações. Também, no fragmento analisado, podemos observar novamente a desvalorização do trabalho doméstico feminino, pois a "unidade doméstica é um dos lugares em que a dominação masculina se manifesta de maneira mais indiscutível" (BOURDIEU, 2010, p. 138). Mais uma vez, os temas da doação à família e a obrigação das tarefas domésticas se sobrepõem à liberdade por ela desejada.

Após a difícil conversa com a filha ao telefone, Francisca começa a separar objetos do falecido marido quando encontra, dentro de livros, provas de que o marido a traía - cartas e uma foto com dedicatória - com Vera Lúcia (Clarisse Abujamra), amiga do casal. A atuação de Selma Egrei deixa evidente sua frustração. Podemos identificar, a partir desse momento, que começa a se consolidar a libertação de Francisca - que vinha se desenhando desde o episódio da camisola - em relação ao poder simbólico do marido e do casamento de maneira mais ampla.

Sentindo-se desapontada com a comprovação do relacionamento extraconjugal do marido, Francisca aceita o convite da vizinha Maria Helena (Joana Fomm) para ir a um baile, onde dança, diverte-se e volta cansada. A 
ida ao baile funciona como um divisor de águas: a mulher, que se dedicou ao marido e de quem a sociedade (na figura do filho) espera o recolhimento ao lar, vai a um baile, entretém-se e parece se dar conta de que ainda há vida para ser vivida. Aos poucos, Maria Helena e Francisca vão se aproximando e nasce um romance entre elas. Na construção narrativa, é interessante perceber que até o momento da descoberta da traição, a trajetória de Francisca vai sendo pautada pelas lembranças do marido e pela constatação de perda do seu papel de esposa, ao mesmo tempo em que tenta libertar-se das recentes imposições e controles do filho. Essas lembranças ganham novas narrativas e se apresentam como pontos de revisão (BRUNER, 1997), uma vez que denotam:

[...] capacidade de visualizar alternativas e conceber outros modos de ser, de agir, engajar-se. Assim, embora possa ser verdade que em certo sentido nós sejamos "criaturas da história", em outro sentido, nós somos também agentes autônomos. [...] E o si-mesmo, usando suas capacidades para a reflexão e para projetar alternativas, evita, adota, ou reavalia o que a cultura tem a oferecer. (BRUNER, 1997, p. 96)

A partir desse momento, é como se uma nova vida começasse para ela, o que é enunciado, de forma poética, numa das últimas cenas do episódio: "Nesses últimos 45 anos, a vida me escapou pelos dedos e pelos medos. E eu não tenho mais tempo para ser covarde diante da possibilidade de ser feliz. Nós não temos, né minha gente? A gente precisa correr". O tema da liberdade e da autorrealização ganha corpo aqui, sobrepujando a antiga opressão e doação completa à família, enfim, a negação de si mesma.

\begin{abstract}
A linguagem condensa, cristaliza e reflete as práticas sociais, ou seja, é governada por formações ideológicas. Ao mesmo tempo, porém, em que é determinada é determinante, pois ela "cria" uma visão de mundo na medida em que impõe ao indivíduo uma certa maneira de ver a realidade, constituindo sua consciência. (FIORIN, 2007, p. 54)
\end{abstract}

Nesse cenário, para os idosos a felicidade e o gozo da liberdade são urgentes, inadiáveis. A frase "só é feio quem quer" também poderia ser ampliada para "só é velho quem quer", não somente considerando a questão estética - que o mercado de cirurgias plásticas e fitness não cansa de incentivar - mas também, e principalmente, a questão psicológica: não ser velho seria atributo de quem é ativo, viaja, busca realizar os sonhos e a felicidade. O que se assemelha bastante à dinâmica do jovem. Chega-se, assim, ao paradoxo de que ser velho, hoje, é ser jovem.

\title{
Considerações
}


No episódio analisado, percebemos, portanto, a construção de um percurso figurativo em que se debatem pontos antagônicos nos discursos da mulher e sobre a mulher. A ideia do papel social feminino de dedicação ao lar, ao marido e aos filhos emana por meio das figuras que desvelam não apenas o papel da mulher na intimidade como também seu papel social. Quanto à tematização, observamos que o percurso temático pode ser comparado a um pêndulo que oscila entre a doação à família/casa/tarefas de mãe e a liberdade recém-conquistada, embora em alguns momentos emane também a solidão. Mais que isso, os percursos narrativos evidenciam não apenas uma dualidade, mas sim uma dicotomia que se revela na destruição da antiga Francisca para que uma nova Francisca surja. Nesse sentido, observamos ainda que prepondera a busca de autorrealização como grande tema dominante, em que fica evidente a urgência da felicidade e da autodescoberta sobretudo para pessoas (idosas) que não têm tempo a perder. Esse reforço dos temas produz a isotopia temática, contribuindo para a força da significação nessa produção teleficcional que aborda as transformações por que passam a mulher, o feminino e a intimidade nos tempos atuais.

Cabe ainda destacar o papel de Folhas de Outono como elemento de construção identitária que bem ilustra tanto a "feminização" da velhice, quanto a emergência e a solidificação do amor confluente em meio às transformações do amor romântico que reverberam no discurso de libertação de Francisca, problematizando os papéis sociais da mulher e da velhice feminina na atualidade.

\section{Referências}

BARROS, Diana Luz Pessoa de. Teoria semiótica do texto. 5. ed. São Paulo: Ática, 2011.

BARROS, Myriam Moraes Lins de. (org.) (2006). Velhice ou terceira idade? Estudos antropológicos sobre identidade, memória e política. 4.ed. Rio de Janeiro: Editora FGV, 2006.

BEAUVOIR, Simone. A velhice: a realidade incômoda. São Paulo: Difusão Europeia do Livro, 1970.

BOURDIEU, Pierre. A dominação masculina. 7. ed. Rio de Janeiro: Bertrand Brasil, 2010.

BRUNER, Jerome. Atos de significação. Porto Alegre: Artes Médicas, 1997.

CASTRO, Gisela. O envelhecimento na retórica do consumo: publicidade e idadismo no Brasil e Reino Unido. In: Encontro da Associação Nacional dos Programas de Pós-Graduação em Comunicação (COMPós), 24., 2015, Brasília. Anais... Brasília: Universidade de Brasília, 2015. 
DEBERT, Guita Grim. A reinvenção da velhice. São Paulo: Editora da Universidade de São Paulo: Fapesp, 2012.

FIORIN, José Luiz. As astúcias da enunciação. São Paulo: Ática, 1996.

FIORIN, José Luiz. Elementos de análise do discurso. 15. ed. São Paulo: Contexto, 2011.

FIORIN, José Luiz. Linguagem e ideologia. 8. ed. São Paulo: Ática, 2007.

FREIRE FILHO, João (org.). Ser feliz hoje: reflexões sobre o imperativo da felicidade. Rio de Janeiro: Editora FGV, 2010.

GIDDENS, Anthony. A transformação da intimidade: sexualidade, amor e erotismo nas sociedades modernas. São Paulo: UNESP, 1993.

GIDDENS, Anthony. Modernidade e identidade. Rio de Janeiro: Jorge Zahar Ed., 2002.

HERNÁNDEZ GARCÍA, Yuliuva. Acerca del género como categoría analítica. Nómadas, Madrid, Espanha, n. 13, enero-junio, 2006.

IBGE. Síntese de Indicadores Sociais: Uma análise das condições de vida da população brasileira. Estudos e Pesquisas, n. 34, 2014. Disponível em: <ftp://ftp.ibge.gov.br/Indicadores_Sociais/Sintese_de_Indicadores_ Sociais_2014/SIS_2014.pdf>. Acesso em: 05 mai. 2015.

MOREIRA, Morvan de Mello. O envelhecimento da população brasileira: intensidade, feminização e dependência. Revista Brasileira de Estudos de População. Brasília, v.15, n.1, p.79-94, 1998.

PRIORE, Mary Del. História do amor no Brasil. 2. ed. São Paulo: Contexto, 2006.

PRIORE, Mary Del. Histórias e conversas de mulher. São Paulo: Planeta, 2013.

SALGADO, Carmen Delia Sánchez. Mulher idosa: a feminização da velhice. Estudos Interdisciplinares sobre o Envelhecimento. Porto Alegre, v. 4, pp.7-19, 2002. Disponível em: <http://www.seer.ufrgs.br/RevEnvelhecer/ article/view/4716>. Acesso em: 10 set. 2013.

SANTOS, Paula. 'Último episódio tem reviravolta chocante', diz Quico Meirelles sobre Os Experientes. Gshow. Online. 01/05/2015. Disponível em: < http://gshow.globo.com/programas/os-experientes/ Extras/noticia/2015/05/ultimo-episodio-tem-reviravolta-chocante-diz-quicomeirelles-sobre-os-experientes.html>. Acesso em: 05 mai. 2015.

SCOTT, Joan. Gênero: uma categoria útil para análise histórica. Educação \& Realidade, Porto Alegre, v. 20, n. 2, jul./dez. 1995, pp. 71-99. 